\title{
The Importance of Healthcare Workers to Comply with Infection Prevention and Control Instructions During COVID-19 Outbreak-A Survey Study
}

\section{COViD-19 Salgını Sırasında Sağlık Çalışanlarının Enfeksiyon Önleme ve Kontrol Yönergelerine Uymalarının Önemi-Bir Anket Çalışması}

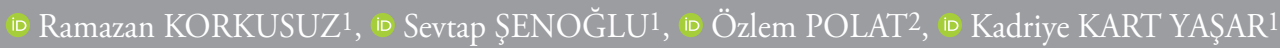

IUniversity of Health Sciences Turkey, Bakırköy Dr. Sadi Konuk Training and Research Hospital, Clinic of Infectious Diseases and Clinical

Microbiology, İstanbul, Turkey

2University of Health Sciences Turkey, Bakırköy Dr. Sadi Konuk Training and Research Hospital, Family Medicine, İstanbul, Turkey

\section{ABSTRACT}

Objective: Taking precations to prevent contamination and developing prevention programs play a key role in the outbreak. For this purpose, the use of personal protective equipment (PPE) of healthcare workers (HCWs) and their compliance with hand hygiene were investigated in the current Coronavirus disease-19 (COVID-19) outbreak.

Methods: In study, $117 \mathrm{HCW}$, who were diagnosed with COVID-19 between 11 March and 18 May 2020, and 117 HCW, who did not meet the case definition, $234 \mathrm{HCW}$ were included in the study, A survey consisting of 28 questions was applied to obtain the research data. The survey consisted of multiple choice questions and was prepared by the researchers using the knowledge of the literature.

Results: It was determined that $65.8 \%$ of the participants were women, $41.9 \%$ were nurses, $82.1 \%$ did not have additional diseases and $62.8 \%$ did not smoke. Positivity was significantly higher in young patients aged 20-30 ( $\mathrm{p}=0.05)$. In the use of PPE, the use of gloves as "always recommended" was found higher in infected HCW with $77.8 \%(\mathrm{p}=0.012)$. The use of overalls/ gowns was found to be statistically significantly lower in infected healthcare workers $(\mathrm{p}=0.01)$. In terms of the hand hygiene application variable after touching the patient between the groups,
ÖZ

Amaç: Salgın sürecinde sağlık çalışanlarında (SÇ) bulaşmayı önlemek açısından önlemlerin alınması ve önleme programlarının geliştirilmesi anahtar role sahiptir. Bu amaçla, halen yaşanmakta olan Koronavirüs hastalığı-19 (COVID-19) salgınında, SÇ’nin kişisel koruyucu ekipmanları (KKE) kullanımı ve el hijyenine uyumu araştırılmıştır.

Yöntemler: Çalışmamızda 11 Mart-18 Mayıs 2020 tarihleri arasında laboratuvar tarafindan doğrulanmış COVİD-19 tanısı alan 117 sağlık çalışanı ile olası olgu tanımını karşılamayan 117 sağlık çalışanı olmak üzere 234 sağlık çalışanı çalışmaya dahil edildi. Araştırma verilerini elde etmek için 28 sorudan oluşan anket uygulanmıştır. Anket, çoktan seçmeli sorulardan oluşmuş ve araştırmacılar tarafından literatür bilgisinden yararlanılarak hazırlanmıştır.

Bulgular: Katılımcıların \%65,8'inin kadın, \%41,9’unun hemşire olduğu, \%82,1'inin ek hastalığının olmadığı, \%62,8'inin sigara kullanmadığı saptanmıştır. Yirmi-30 yaş arası genç hastalarda pozitiflik anlamlı oranda yüksek saptanmıştır $(\mathrm{p}=0,05)$. KKE "her zaman önerildiği gibi” şeklinde eldiven kullanımı \%77,8 ile enfekte SÇ’lerde daha yüksek bulunmuştur $(p=0,012)$. Özellikle tulum/önlük kullanımı enfekte SÇ’lerinde istatistiksel açıdan anlamlı olarak düşük saptanmıştır $(\mathrm{p}=0,01)$. Gruplar arasında hastaya dokunduktan sonra el hijyeni uygulama değişkeni açısından

*This work was supported by Wiley.

Address for Correspondence: Ramazan KORKUSUZ, University of Health Sciences Turkey, Bakırköy Dr. Sadi Konuk Training and Research Hospital, Clinic of Infectious Diseases and Clinical Microbiology, İstanbul, Turkey

Cite this article as: Korkusuz R, Şenoğlu S, Polat Ö, Kart Yaşar K. The Importance of Healthcare Workers to Comply with Infection Prevention and Control Instructions During COVID-19 Outbreak-A Survey Study. Bezmialem Science. 2021;9(Supplement 1):32-39. 


\section{ABSTRACT}

compliance was found to be low in healthcare workers diagnosed with COVID-19 ( $\mathrm{p}=0.005)$.

Conclusion: It was observed that the risks of healthcare workers getting COVID-19 decreased significantly if the infection control measures were followed. It is thought that it would be beneficial to investigate new methods to ensure that protective measures are fully implemented by HCW.

Keywords: Healthcare workers, COVID-19, personal protective equipment, hand hygiene

\section{ÖZ}

COVID-19 tanılı SÇ’lerinde uyumun düşük olduğu saptanmıştır $(\mathrm{p}=0,005)$.

Sonuç: Enfeksiyon kontrol önlemlerine uyulduğu takdirde SÇ’lerin COVID-19'a yakalanma risklerinin anlamlı olarak düştüğü gözlenmiştir. Buna rağmen, COVİD-19 pandemisi sürecinde, SÇ’lerin KKE kullanımındaki eksikliklerini görmek, KKE protokollerini iyileştirmek ve eğitimlerini yenilikçi yöntemler kullanarak geliştirmek için detaylı araştırmalara ihtiyaç vardır.

Anahtar Sözcükler: Sağlık çalışanları, COVİD-19, kişisel koruyucu ekipman, el hijyeni

\section{Introduction}

Healthcare workers (HCWs) are at risk of contracting lifethreatening infectious diseases due to contact with patients' blood, mucus, discharge or aerosol droplets. Especially during epidemics, this risk is higher among HCWs compared to the general population. Due to the increase in the number of infected HCWs during epidemics, the overloaded healthcare system may be in a difficult situation due to the loss of workforce. In Wuhan, China, "severe acute respiratory syndrome coronavirus" (SARS-COV-2) with viral pneumonia started to appear in December 2019 (1). The World Health Organization (WHO) declared this disease, which spreads rapidly in the world, as "International Public Health Emergency" on January 30, 2020 and as a pandemic on March 11, 2020 (2,3). As of May 18, $2020 ; 4,618,821$ cases in the world and in Turkey 150,593 cases have been reported (4,5). As of April 8, 2020, the number of $\mathrm{HCW}$ diagnosed with Coronavirus disease-19 (COVID-19) in the world was reported as 22073 by WHO (6). In Turkey, according to the description of the the Ministry of Health, 7428 health care workers has been infected as of April 30, 2020 (7). Although the main transmission routes of COVID-19 disease are through droplets and contact, other transmission routes are also possible (8). Compliance with hand hygiene and the use of personal protective equipment (PPE) are the most important measures for HCWs exposure control. While overalls, gowns, masks, glasses and face shields prevent the skin and mucous from being contaminated, the mask prevents droplet inhalation. The indications for the use of PPE for HCW, which is and is not directly interested in the care of COVID-19 patients, have been specified by WHO (9). During the epidemic process, taking the necessary precautions and developing precaution programs to prevent contamination in the HCW has a key role. However, determining the contamination and protective measures by taking into account the characteristics of individual, procedural and health institutions will be effective in developing the targeted part of prevention programs. Our hospital, Istanbul/Turkey, as mandated by the Ministry of Health hospital pandemic and has been one of the centers most patients have been followed. Our hospital is a tertiary hospital with 612 beds and 2737 (724 physicians, 864 nurses, 10 pharmacists, 978 auxiliary health personnel, 161 technicians and technicians) HCW. In our study, the correct use of PPE and the effectiveness of hand hygiene by HCWs during the epidemic process were investigated.

\section{Method}

HCW with a laboratory-confirmed diagnosis of COVID-19 between March 11 and May 18, 2020, and HCW without any complaint and considered not to be infected, as a control group, were included in the study. The study protocol was approved by the Ethics Committee of Bakırköy Dr. Sadi Konuk Training and Research Hospital, University of Health Sciences Turkey (18.05.2020/2020-11). The study was a descriptive and crosssectional study and was conducted as a single center study. Participants consisted of clinicians, nurses and assistant health personnel.

HCW working in the COVID service, providing care to the patient or entering the patient room, participated voluntarily in the study was included to the study. HCW that works in a nonCOVID ward, does not provide care to the patient or does not enter the patient's room and does not approve the participation of the questionnaire were excluded from the study. Out of a total of 181 HCWs diagnosed with COVID-19, 117 HCWs meeting the inclusion criteria and $117 \mathrm{HCW}$ s as control groups were included in the study. A total of $234 \mathrm{HCW}$ included in the study.

Due to the risk of contamination, approvals for participation in the study and questionnaire filling procedures were carried out by phone or online. A questionnaire consisting of 28 questions was applied to $234 \mathrm{HCW}$ to obtain research data. The questionnaire consists of multiple choice questions and was prepared by the researchers using the literature knowledge.

The questionnaire consists of multiple choice questions and was prepared by the researchers using the literature knowledge. Questions about socio-demographic characteristics (age, gender, comorbidities, occupational duty and working hours) in the first part of the questionnaire prepared in four parts; In the second part, the presence of domestic COVID-19 patients, contact with an out-of-hospital COVID-19 patient, application of aerosolforming procedure to a COVID-19 patient (taking respiratory 
tract samples, intubation, airway care and cardiac arrest), contact with biological material (contact of the patient with blood, body fluids, secretions); In the third part, the existence of protective equipment and in the last part, questions about hand hygiene compliance are given.

\section{Statistical Analysis}

The normality distribution of the data obtained from the participants (Kolmogorov-Smirnov) was made and it was determined that they were not distributed normally. For this reason, nonparametric tests were applied. Number and percentage distributions of the data obtained from the participants were made, and chi-square analysis was performed to test the difference between groups. The level of significance was taken as $\mathrm{p} \leq 0.05$.

\section{Results}

It was determined that $34.2 \%$ of the participants were male, $65.8 \%$ were female, $73.1 \%$ were under the age of $40,82.1 \%$ had no comorbidities, $62.8 \%$ did not smoke, $41.9 \%$ were nurses. Positivity was significantly higher in young patients between the ages of 20-30 $(p=0.05)$. Socio-demographic variables in comparison of the groups are presented in Table 1.
The rate of diagnosing COVID-19 among family members is $35 \%$ in the infected HCWs group, and was higher than the control group $(\mathrm{p}<0.001)$. A statistically significant difference was found when compared to the other group in terms of face-to-face contact with the COVID-19 patient without a mask ( $\mathrm{p}=0.024)$. In the control group, $52 \%$ of being in the same environment during the implementation of aerosol-forming procedures was detected, and this rate was found to be $18 \%$ higher than the rate we found in infected HCW $(\mathrm{p}=0.006)$. The clinical practice and contact variables of the healthcare professionals are presented in Table 2 .

When the two groups were compared in terms of the use of PPE, the use of gloves as "always, as recommended" was found to be higher in infected HCW with a rate of $77.8 \%(\mathrm{p}=0.012)$ (Table 3 ). Although there was no statistical difference between the two groups in terms of the use of N95 mask, face shield/glasses, it was observed that the compliance was lower in infected HCW as a percentage. Especially the use of overalls/aprons was found to be statistically significantly lower in infected HCW $(\mathrm{p}=0.01)$.

While there were no differences between the groups in the appropriate change of PPEs according to the procedure, before and after contact with the patient, before and after the aseptic

Table 1. Sociodemographic variables

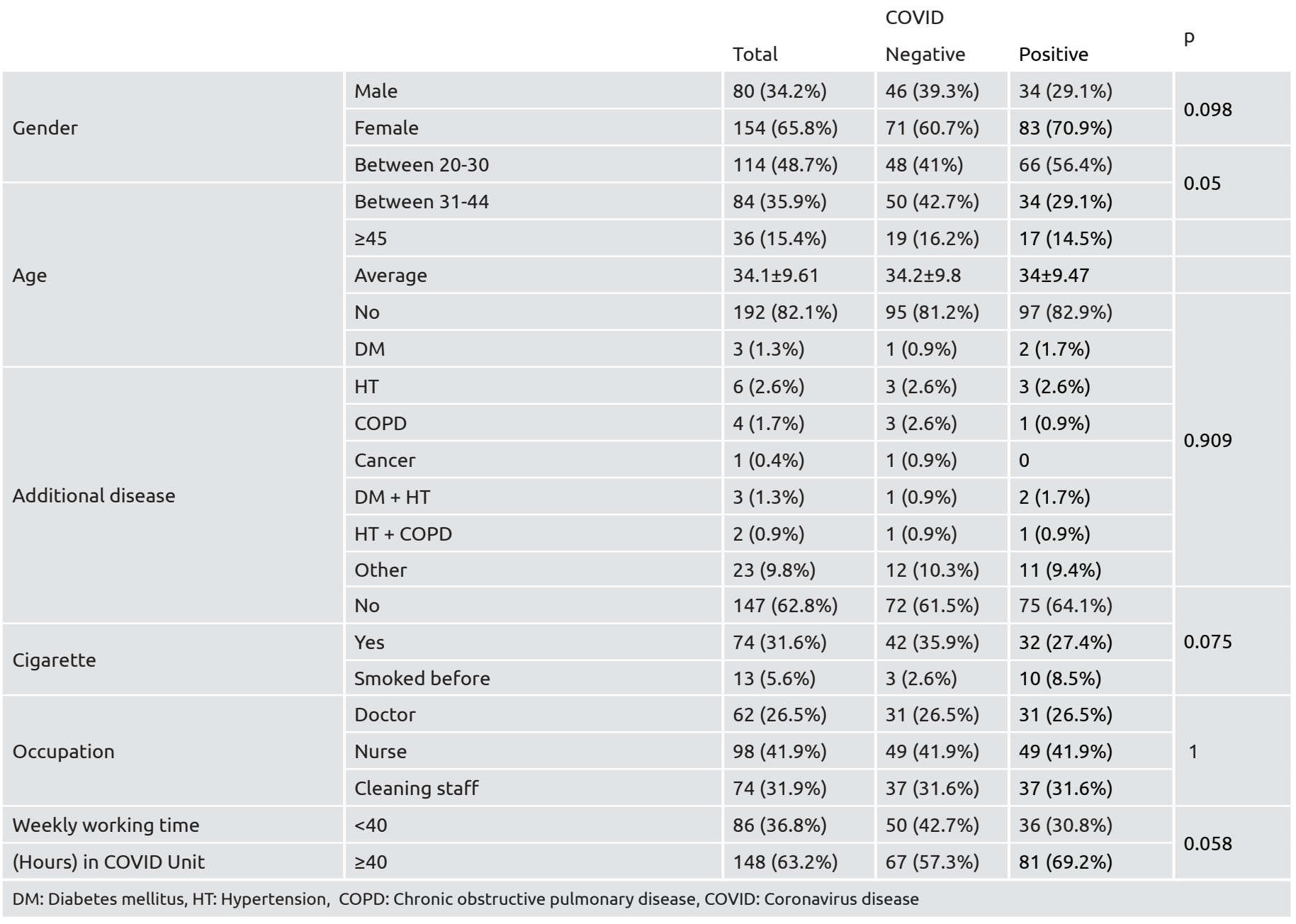


Table 2. Clinical practice and contact variables

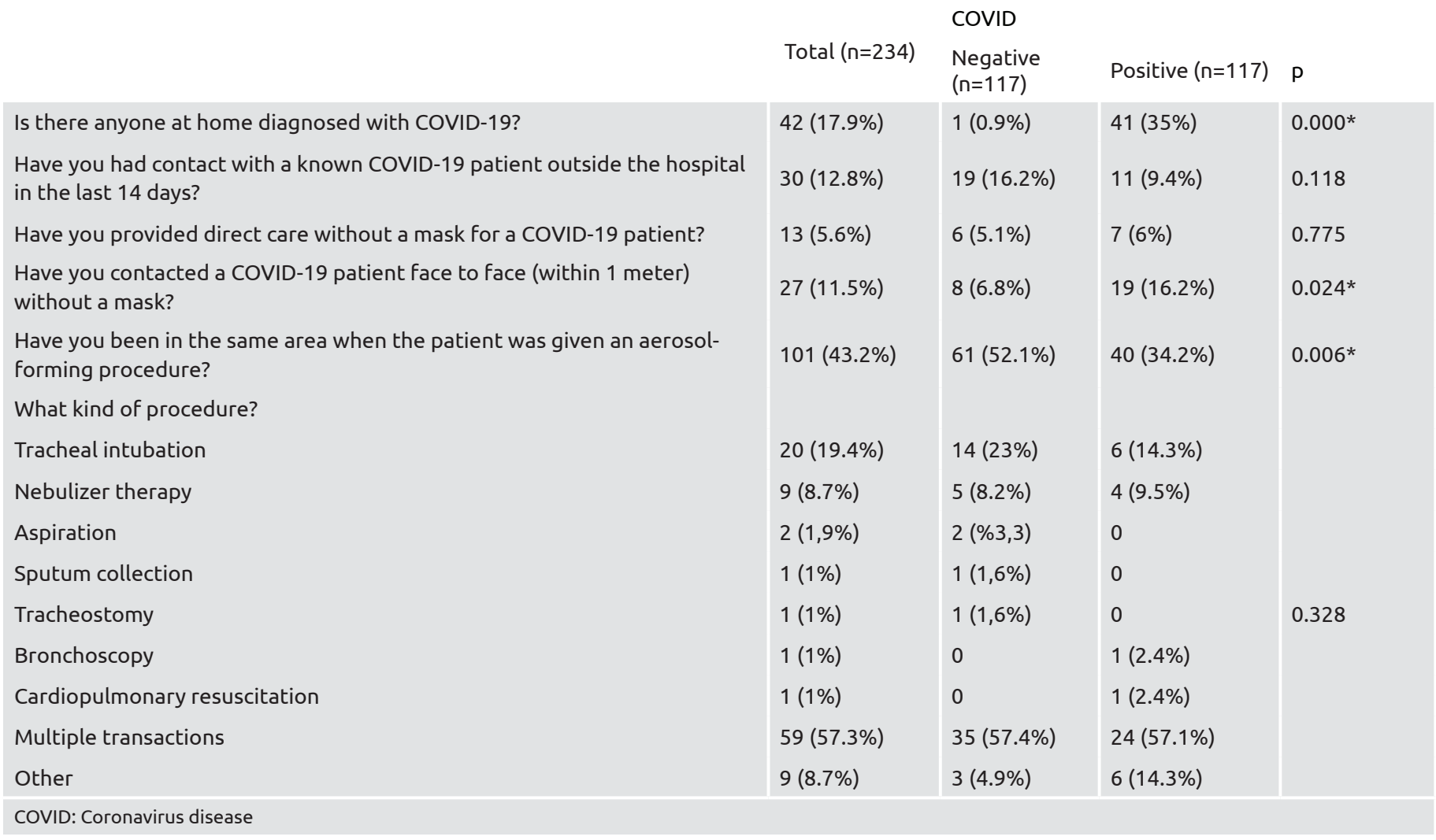

procedure, and after contact with body fluids, compliance with the indication to perform hand hygiene after touching the positive patient's environment was found to be low in infected HCW ( $\mathrm{p}=0.005)$. Differences between hand hygiene compliance are shown in Table 4.

No statistically significant difference was found between the groups in terms of infected patient excretions and having an accident ( $>>0.05)$ (Table 5).

\section{Discussion}

Usually, recall bias in questionnaires is a point of concern. However, it was thought that the questions were open and the requested information was about simple concrete behaviors and about recent events, so it was not at a level that would affect the results. When the socio-demographic risk factors in terms of SARS-COV-2 infection were compared in comparison of the HCW groups participating in the questionnaire, gender, comorbidities and smoking were found to be similar and no statistically significant difference was found ( $p>0.05)$. The more positivity in the young (20-30 years old) HC group ( $\mathrm{p}=0.05)$, the milder course of the disease in the young people, and the experience of the senior HCW were evaluated as more adhering to the prevention methods.

It has been observed that having a smoking habit does not differ in terms of contamination. As far as we researched from the English literature, there are no studies evaluating the risk of SARS-CoV-2 infection among smokers. It was evaluated that more detailed studies should be done on this subject. In one study, it was stated that long working hours increased the risk of respiratory tract infection transmission, and moderate working hours were safer for HCWs (10). In terms of weekly working hours, the working time of 40 hours or more in infected HCW is more with a rate of $69.2 \%$, but no statistical significance was found $(\mathrm{p}>0.05)$.

However, according to the characteristics of HCW, it has been evaluated that the hours he worked will be important in terms of viral transmission during the pandemic period. Due to the relatively small sample size of our study, it was thought that this variable might not have significance. The highest infection rate among HCW was observed in nurses. It was thought that this situation may be caused by nurses' closer and longer contact with patients.

During the pandemic process, HCWs can infect family members as well. In our study, it was observed that family members of 41 (35\%) of infected HCW were also infected. In the control group, only $1(0.9 \%)$ family member was found to have COVID-19 $(p<0.001)$. This shows that there is an increased risk of disease transmission in family members of HCW diagnosed with COVID-19.

Ran et al. (11) stated in his research that the procedures that create aerosol in the use of appropriate PPE are not associated with the risk of infection transmission of HCWs. In our study, the fact that the application of the procedure that creates aerosol to the COVID-19 patient was higher in non-infected HCW, 
Table 3. Use of personal protective equipment

\begin{tabular}{|c|c|c|c|c|}
\hline & Total $(n=234)$ & COVID & & $p$ \\
\hline $\begin{array}{l}\text { Have you used personal protective equipment during healthcare } \\
\text { interaction with a COVID-19 patient? }\end{array}$ & & Negative $(n=117)$ & Positive ( $n=117$ ) & \\
\hline \multicolumn{5}{|l|}{ Gloves only } \\
\hline Everytime, as suggested & $162(69.2 \%)$ & $71(60.7 \%)$ & $91(77.8 \%)$ & \\
\hline Rarely & $3(1.3 \%)$ & $3(2.6 \%)$ & 0 & \\
\hline \multicolumn{5}{|l|}{ Medical mask } \\
\hline Everytime. as suggested & $188(80.3 \%)$ & $88(75.2 \%)$ & $100(85.5 \%)$ & \\
\hline Most of the time & $30(12.8 \%)$ & $19(16.2 \%)$ & 11 (9.4\%) & 212 \\
\hline Everytime, as suggested & $148(63.2 \%)$ & $77(65,8 \%)$ & $71(60,7 \%)$ & \\
\hline Most of the time & $47(20.1 \%)$ & $24(20.5 \%)$ & $23(19.7 \%)$ & 0642 \\
\hline Sometimes & $18(7.7 \%)$ & $8(6.8 \%)$ & $10(8.5 \%)$ & 0,642 \\
\hline Rarely & $21(9 \%)$ & $8(6.8 \%)$ & $13(11.1 \%)$ & \\
\hline \multicolumn{5}{|l|}{ Face shield or goggles/protective goggles } \\
\hline Everytime. as suggested & $107(45.7 \%)$ & $61(52.1 \%)$ & $46(39.3 \%)$ & \\
\hline Most of the time & $74(31.6 \%)$ & $37(31.6 \%)$ & $37(31.6 \%)$ & 0066 \\
\hline Sometimes & $26(11.1 \%)$ & 11 (9.4\%) & $15(12.8 \%)$ & 0.000 \\
\hline Rarely & $41(17.5 \%)$ & $13(11.1 \%)$ & $28(23.9 \%)$ & \\
\hline \multicolumn{5}{|l|}{$\begin{array}{l}\text { During the healthcare interaction with the COVID-19 patient. did } \\
\text { you remove and replace the Protective equipment according to the } \\
\text { protocol (for example, wet PPE when the medical mask got wet) }\end{array}$} \\
\hline Everytime, as suggested & 167 (71.4\%) & $80(68.4 \%)$ & 87 (74.4\%) & \\
\hline Most of the time & $52(22.2 \%)$ & $29(24.8 \%)$ & $23(19.7 \%)$ & 0.575 \\
\hline Sometimes & $14(6 \%)$ & $7(6 \%)$ & $7(6 \%)$ & \\
\hline Rarely & $1(0.4 \%)$ & $1(0.8 \%)$ & 0 & \\
\hline
\end{tabular}

showed the importance of compliance with infection prevention and control guidelines in preventing contagiousness.

The risk of SARS-COV-2 infection is highly dependent on the distance from the patient. Studies have reported that a physical distance of at least 1 meter with the patient can have a strong protective effect (12). During the pandemic, close contact of HCW with patients for a long time increases the possibility of transmission. In our study, the contact of infected HCW with a COVID-19 patient face to face (within 1 meter) without a mask was $16.2 \%$, and it was found to be significantly higher than the control group $(\mathrm{p}=0.024)$. At the beginning of the pandemic process, it was thought that COVID-19 patients were hospitalized in different clinics with other diagnoses, and HCE was especially infected as a result of the use of unmasked or partial PPE in patient care.

Research has shown that since the transmission of SARS-COV-2 infection is through contact and droplets, medical masks (when combined with other PPEs, including face shields and hand 
Table 4. Hand hygiene compliance

\begin{tabular}{|c|c|c|c|c|}
\hline & Total & COVID & & $\mathrm{P}$ \\
\hline & (10) & Negative ( $n=117)$ & Positive ( $n=117$ ) & \\
\hline $\begin{array}{l}\text { Have you practiced hand } \\
\text { a COVID-19 patient? }\end{array}$ & & & & \\
\hline Everytime, as suggested & 159 (67.9\%) & $88(75.2 \%)$ & $71(60.7 \%)$ & \\
\hline Most of the time & $68(29.1 \%)$ & $26(22.2 \%)$ & 42 (35.9\%) & 0.057 \\
\hline Everytime, as suggested & $173(73.9 \%)$ & $88(75.2 \%)$ & 85 (72.6\%) & \\
\hline Most of the time & $53(22.6 \%)$ & $24(20,5 \%)$ & $29(24.8 \%)$ & \\
\hline Sometimes & $5(2.1 \%)$ & $3(2.6 \%)$ & $2(1.7 \%)$ & 0.101 \\
\hline Everytime, as suggested & 214 (91.5\%) & 103 (88\%) & $111(94,9 \%)$ & \\
\hline Most of the time & $16(6.8 \%)$ & $12(10,3 \%)$ & $4(3,4 \%)$ & 131 \\
\hline Sometimes & $1(0.4 \%)$ & 0 & $1(0,9 \%)$ & (1) \\
\hline Rarely & $3(1.3 \%)$ & $2(1,7 \%)$ & $1(0,9 \%)$ & \\
\hline $\begin{array}{l}\text { Have you practiced hand } \\
\text { COVID-19 patient's surre }\end{array}$ & & & & \\
\hline Everytime, as suggested & $157(67.1 \%)$ & $90(76.9 \%)$ & $67(57.3 \%)$ & \\
\hline Most of the time & $69(29.5 \%)$ & $23(19.7 \%)$ & 46 (39.3\%) & $0005 *$ \\
\hline Sometimes & $4(1.7 \%)$ & $1(0.9 \%)$ & $3(2.6 \%)$ & \\
\hline Rarely & $11(4.7 \%)$ & $7(6 \%)$ & $4(3.4 \%)$ & \\
\hline
\end{tabular}

hygiene) are sufficient during non-aerosol care, and N95 masks are prominent compared to medical masks during routine care. It suggests that it does not provide any benefit (13).

In a study conducted in Hong Kong, 11 (2.7\%) of a total of $413 \mathrm{HCWs}$ used medical masks for routine care of COVID-19 patients and none of them developed infection (14). In our study, the compliance of infected HCW in the use of N95 mask "always, as recommended" is low as $60.7 \%$. Although the compliance of the control group to use N95 mask was 5\% higher, there was no statistically significant difference between the groups.

Studies have reported that the use of PPE reduces the risk of infection in HCWs (15-18). In the use of PPE, the rate of using gloves as "always, as recommended" between the two groups was found to be higher in infected HCW with 77.8-60.7\% $(\mathrm{p}=0.012)$. While the rate of using face shield/glasses was low in both groups, the use of "always, as recommended" in infected
HC was 13\% lower. This rate was not statistically significant. Especially in the use of overalls/aprons, the use of "always, as recommended" was low in both groups, but a higher compliance was observed at a rate of $52.1 \%$ in the control group while it was $34.2 \%$ in infected HCWs $(p=0.01)$. Our research suggests that no personnel will be infected if they use all four precautions as always recommended in the rules of wearing gloves, masks, eye protection and apron for PPE use.

The risk of disease transmission increases in case of unprotected contact with biological materials in HCWs $(16,19)$. In our study, no significant difference was found between the groups in those who had unprotected contact with biological materials.

Another way of transmission of the SARS-COV-2 virus is through contact. The most important tool of the virus that facilitates indirect contact transmission is contaminated hands. In our study, in line with the answers given according to the " 5 - 
Table 5. Contact with sick body fluid/respiratory secretions

\begin{tabular}{|c|c|c|c|c|}
\hline & \multirow{2}{*}{ Total } & \multicolumn{2}{|l|}{ COVID } & \multirow{2}{*}{$\mathrm{p}$} \\
\hline & & Negative & Positive & \\
\hline $\begin{array}{l}\text { Healthcare worker with a history of contact with biological fluid/respiratory secretions } \\
\text { during the healthcare interaction period with a patient infected with COVID-19 }\end{array}$ & $10(4.3 \%)$ & $5(4.3 \%)$ & $5(\% 4.3$ & 1 \\
\hline Splash of biological fluid/respiratory secretions on the mucous membrane of the eyes & $3(30 \%)$ & $3(60 \%)$ & 0 & \\
\hline Spatter of biological fluid/respiratory secretions on the oral/nasal mucosa & $4(40 \%)$ & $1(20 \%)$ & $3(60 \%)$ & 0.115 \\
\hline Splash of biological fluid/respiratory secretions on intact skin & $3(30 \%)$ & $1(20 \%)$ & $2(40 \%)$ & \\
\hline
\end{tabular}

step hand hygiene" rule, hand hygiene before and after touching the patient in infected HCW was found to be $60.7 \%$ as recommended, while it was higher in the control group with $75.2 \%$.

Likewise, hand hygiene compliance after touching the patient's environment in the control group $\mathrm{HC}$ was found to be significantly higher with $76.9-57.3 \%$ compared to the infected $\mathrm{HC}(\mathrm{p}=0.005)$. As a result, it has been observed that compliance with the "5-step hand hygiene" rule in line with the WHO recommendation to prevent the spread of the COVID-19 virus is extremely important in preventing infection transmission (20).

\section{Study Limitations}

The limitations of the study are that our study was singlecentered, the number was relatively low, it was based on the questionnaire rather than direct observation, and the SARSCOV-2 polymerase chain reaction test of the HCW taken as the control group was not examined.

\section{Conclusion}

As a result, it has been observed that as the compliance with the infection control measures and directives decreases, the risk of contamination of COVID-19 to HCW increases. In addition, it has been observed that partial compliance with protective measures does not prevent the risk of disease transmission. It is noteworthy that there is an increased risk of disease transmission in family members of HCW diagnosed with COVID-19. This situation is important due to both employee and public health and prolonged labor losses. It is thought that it would be beneficial to research new methods that will ensure the full implementation of protective measures by the HCW and to provide training using innovative methods.

\section{Ethics}

Ethics Committee Approval: The study protocol was approved by the Ethics Committee of University of Health Sciences Turkey Bakırköy Dr. Sadi Konuk Training and Research Hospital(18.05.2020/2020-11).

Informed Consent: Signed informed consent was obtained from all participants before study.

Peer-review: Externally and internally peer reviewed.

\section{Authorship Contributions}

Surgical and Medical Practices: R.K., Concept: Ö.P., K.K.Y., Design: R.K., K.K.Y., Data Collection or Processing: Ö.P.,
Analysis or Interpretation: S.Ş., K.K.Y., Literature Search: S.Ş., Writing: R.K.

Conflict of Interest: No conflict of interest was declared by the authors.

Financial Disclosure: This work was supported by Wiley.

\section{References}

1. Huang C, Wang Y, Li X, Ren L, Zhao J, Hu Y, et al. Clinical features of patients infected with 2019 novel coronavirus in Wuhan, China. Lancet 2020;395:497-506.

2. WHO. Statement on the second meeting of the International Health Regulations (2005) Emergency Committee regarding the outbreak of novel coronavirus (2019-nCoV). Last Accessed Date: 06.06.2020 Available from: https://www.who.int/news/item/30-012020-statement-on-the-second-meeting-of-the-international-healthregulations-(2005)-emergency-committee-regarding-the-outbreakof-novel-coronavirus-(2019-ncov).

3. World Health Organization. WHO Director-General's opening remarks at the media briefing on COVID-19-11 March 2020. Last Accessed Date: 30.05.2020. Available from: https://www.who.int/ director-general/speeches/detail/who-director-general-s-openingremarks-at-the-media-briefing-on-covid-19---11-march-2020.

4. World Health Organization. Coronavirus disease (COVID-19) Situation Report-119. Last Accessed Date: 06.06.2020 Available from: https://www.who.int/docs/default-source/coronaviruse/situationreports/20200518-covid-19-sitrep-119.pdf?sfvrsn=4bd9de25_4.

5. T.C. Sağlık Bakanlığı. Rebuplic of Turkey Ministry of Health. Coronavirus disease 2019 (COVID-19) Current Status. Last Accessed Date: 18.05.2020. Available from: https://covid19bilgi. saglik.gov.tr/tr/.

6. World Health Organization. Coronavirus disease 2019 (COVID-19) Situation Report-82. Last Accessed Date: 06.06.2020. Available from: https:/www.who.int/docs/default-source/coronaviruse/situationreports/20200411-sitrep-82-covid-19.pdf?sfvrsn=74a5d15_2.

7. https://www.aa.com.tr/en/health/turkey-currently-passing-overpeak-of-pandemic/1823201. Accessed 06 June 2020.

8. Chan JF, Yuan S, Kok KH, To KK, Chu H, Yang J, et al. A familial cluster of pneumonia associated with the 2019 novel coronavirus indicating person-to-person transmission: A study of a family cluster. Lancet 2020;395:514-23.

9. World Health Organization. Rational use of personal protective equipment (PPE) for coronavirus disease (COVID-19): interim 
guidance, 19 March 2020. Institutional Repos Inf Shar 2020:7 Accessed 06 June 2020.

10. Weaver MD, Landrigan CP, Sullivan JP, O’Brien CS, Qadri S, Viyaran $\mathrm{N}$, et al. The association between resident physician work-hour regulations and physician safety and health. Am J Med 2020;133:343-54.

11. Ran L, Chen X, Wang Y, Wu W, Zhang L, Tan X. Risk factors of healthcare workers with coronavirus disease 2019: A retrospective cohort study in a designated hospital of Wuhan in China. Clin Infect Dis 2020;71:2218-21.

12. Chu DK, Akl EA, Duda S, Solo K, Yaacoub S, Schünemann HJ; et al. Physical distancing, face masks, and eye protection to prevent person-to-person transmission of SARS-CoV-2 and COVID-19: A systematic review and meta-analysis. Lancet 2020;395:1973-87.

13. Bartoszko JJ, Farooqi MAM, Alhazzani W, Loeb M. Medical masks vs N95 respirators for preventing COVID-19 in healthcare workers: A systematic review and meta-analysis of randomized trials. Influenza Other Respir Viruses 2020;14:365-73.

14. Cheng VCC, Wong SC, Chen JHK, Yip CCY, Chuang VWM, Tsang OTY, et al. Escalating infection control response to the rapidly evolving epidemiology of the coronavirus disease 2019 (COVID-19) due to SARS-CoV-2 in Hong Kong. Infect Control Hosp Epidemiol 2020;41:493-8.
15. Pei LY, Gao ZC, Yang Z, Wei DG, Wang SX, Ji JM, et al. Investigation of the influencing factors on severe acute respiratory syndrome among health care workers. Beijing Da Xue Xue Bao Yi Xue Ban 2006;38:271-5.

16. Raboud J, Shigayeva A, McGeer A, Bontovics E, Chapman M, Gravel $D$, et al. Risk factors for SARS transmission from patients requiring intubation: A multicentre investigation in Toronto, Canada. PLoS One 2010;5:10717.

17. Teleman MD, Boudville IC, Heng BH, Zhu D, Leo YS. Factors associated with transmission of severe acute respiratory syndrome among health-care workers in Singapore. Epidemiol Infect 2004;132:797-803.

18. Yin WW, Gao LD, Lin WS, Gao LD, Lin WS, Du L, et al. [Effectiveness of personal protective measures in prevention of nosocomial transmission of severe acute respiratory syndrome]. Zhonghua Liu Xing Bing Xue Za Zhi 2004;25:18-22.

19. Scales DC, Green K, Chan AK, Poutanen SM, Foster D, Nowak K, et al. Illness in intensive care staff after brief exposure to severe acute respiratory syndrome. Emerg Infect Dis 2003;9:1205-10.

20. WHO. Interim recommendations on obligatory hand hygiene against transmission of COVID-19. Last Accessed Date: 08.06.2020. Available from: https://www.who.int/publications/m/item/ interim-recommendations-on-obligatory-hand-hygiene-againsttransmission-of-covid-19. 